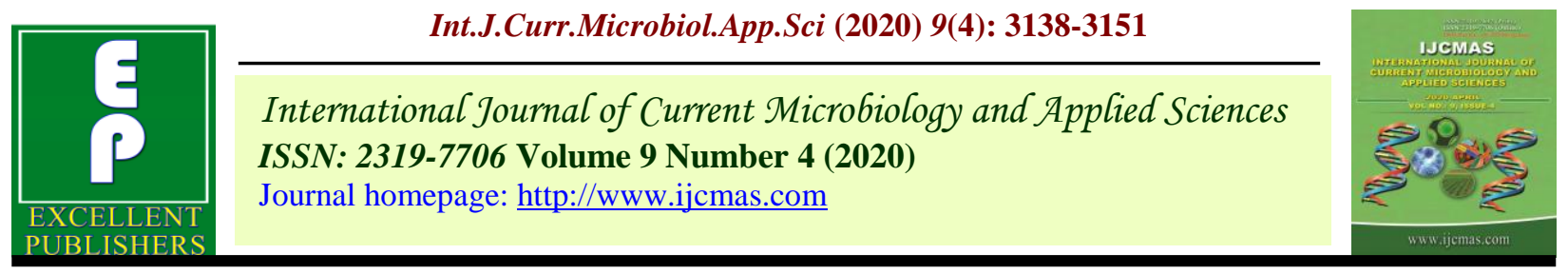

Original Research Article

https://doi.org/10.20546/ijcmas.2020.904.366

\title{
Effect of Different Moisture Regimes on the Yield, Quality and Water Use Efficiency of Chrysanthemum var. Marigold
}

\author{
S. Vijayakumar*, R. H. Laxman, Sujatha Anil Nair and Anil Kumar Nair \\ ICAR - Indian institute of Horticultural Research, Bangalore, Karnataka, India \\ *Corresponding author
}

\begin{tabular}{|l|}
\hline Ke y w o r d s \\
Chrysanthemum, \\
$\begin{array}{l}\text { Field capacity, } \\
\text { Gravimetric } \\
\text { method, WUE, Gas } \\
\text { exchange } \\
\text { characteristics and } \\
\text { biomass }\end{array}$ \\
\hline Article Info \\
\hline $\begin{array}{l}\text { Accepted: } \\
28 \text { March } 2020 \\
\text { Available Online: } \\
\text { 10 April } 2020\end{array}$ \\
\hline
\end{tabular}

\section{A B S T R A C T}

The performance and water use efficiency (WUE) of Chrysanthemum var. Marigold was evaluated under two moisture regimes, i.e., $100 \% \mathrm{FC}$ and $70 \% \mathrm{FC}$ imposed and maintained using gravimetric method. At $100 \% \mathrm{FC}$, the plant height $(30.33 \mathrm{~cm})$, average plant spread $(38.21 \mathrm{~cm})$, number of primary branches/plant (5.67) and secondary branches/plant (4.67), number of leaves/plant (71.67), number of flowers/plant (136.75), average weight of individual flowers (7.21g), RWC (94.29\%), root: shoot ratio (0.42), total fresh bio mass (153.09 g), flower yield (881.67 g / plant) and shelf life of 7.58 days were significantly higher compared to plants grown under $70 \%$ FC. The gas exchange characteristics i.e. photosynthetic rate, stomatal conductance and transpiration rate were also significantly higher in plants grown at $100 \%$ field capacity compared to $70 \%$ field capacity treatment. However, the water use efficiency (WUE) of chrysanthemum was higher at $70 \% \mathrm{FC}$ (39.82 g/litter) compared to $100 \% \mathrm{FC}$ ( $22.38 \mathrm{~g} /$ litter). The results of the study showed that, the plants maintained under $100 \%$ FC produced a greater number of flowers with enhanced shelf life compared to plants grown under $70 \%$ FC. Hence it is suggesting that Chrysanthemum var. Marigold performed better in higher moisture regime than 70 $\%$ FC level.

\section{Introduction}

Chrysanthemum (Dendranthema grandiflora Tzvelev.) belonging to the family Asteraceae is cultivated for its attractive coloured flowers (Koley and Sarkar, 2013). It is one of the most important commercial flower crops grown in different parts of the world for loose flowers, cut flowers and as potted plant. Among the factors that influence production, proper management of water is a fundamental requirement for cultivation of flowers. Photosynthesis, biomass production and dry matter play a vital role on the visual quality of ornamental plants. One of the most important factors that affects this in plants is water potential (Jones and Tardieu 1998; Peri et al., 2003). Therefore, optimizing water management is an important step to determine the effects of water on the growth period of 
ornamental plants as well as their visual quality (Carvalho et al., 2005; Lin et al., 2011). Hence, it is obligatory to consider different factors such as soil, plant and water resource in order to irrigate larger areas with the current water resources and to prevent possible efficiency and quality losses. In addition, the amount of plant water consumption under either sufficient or deficient water conditions throughout the growing period of plants need to be understood in order to assess the water-yield relationships. Efficient use of limited water resources and enhanced growth under limited water supply are desirable traits for crops in drought conditions (Jaleel et al., 2008) and also there is a need to sustain production and quality of flowers under water limiting situations. The efficiency for producing dry matter per unit of applied water, and the ability to allocate an increased proportion of the biomass into economic parts are important factors.

Water use efficiency (WUE) is the ability of the crop to produce biomass per unit of water transpired, and harvest index is the fraction of total dry matter harvested as yield. Studies evaluating a plant's response to water are often performed under greenhouse or controlled environmental conditions, with the plants growing in pots to maintain them at certain water stress level through gravimetric method for a limited time or throughout the growing period (Chandi et al., 2013; Chauhan 2013; Chauhan and Johnson 2010; Earl 2003; Sarangi et al., 2015). The widely used direct method is the gravimetric method or thermostat-weight technique for quantification of WUE (Schmugge et al., 1980) and is accurate and inexpensive (Dobriyal et al., 2012). A gravimetrical determination of water consumption provides the exact amount of irrigation water to be applied to the plants (Andersson, 2001).
The majority of the investigations on chrysanthemum are in the level of field evaluation (Jawaharlal et al., 2017; Arif et al., 2015; Janakiram et al., 2006; Sohier et al., 2008 and Ngouajio et al., 2007) and their studies are mainly concentrated on effect different irrigation treatments on yield and quality of chrysanthemum.

Janakiram et al., (2006) reported that overall comparison of growth parameters, yield and quality of flowers were found to be better with less irrigation $(40 \quad \mathrm{kPa})$ in chrysanthemum cv. Yellow Regan. According to Sohier et al., (2008) the maximum plant height $(77 \mathrm{~cm})$, number of leaves (60 nos./plant.) and stem dry weight (8.27 g/plant) was observed with $75 \%$ of irrigation water in chrysanthemum cv. Wilson's white. Plants grown under irrigation water of $400 \mathrm{ml}$ at 6 times/day in $140 \mathrm{~cm}^{3}$ substrates produced the tallest plant of $109.25 \mathrm{~cm}$ in chrysanthemum cv. White Regan (Tasweek et al., 2014). Jawaharlal et al., (2017) reported that irrigation scheduled at $0.6 \mathrm{E}$ pan had shown the highest water use efficiency $(111.09 \mathrm{~kg}$ $\mathrm{ha} / \mathrm{mm}$ ). Turan et al., (2015) revealed that increased amount of irrigation water applied $(517.9 \mathrm{~mm})$ to the plants produced maximum yield of 30.09 flowers/plant in chrysanthemum cv. Bacardi. Irrigation management with daily replacements of $175 \%$ of the crop evapotranspiration, corresponding to a daily average irrigation depth of 12.25 $\mathrm{mm}$, showed the best results for all evaluated morphological parameters, that is primordial for the increase of the chrysanthemums quality cv. Puritan (Posse et al., 2019). Hence with respect to chrysanthemum no study has been done to quantify water use efficiency by gravimetric method with field capacity-based moisture regimes in pot culture for improved growth, yield and quality of chrysanthemum. Hence, the present investigation was undertaken to study the water use efficiency, growth and yield performance of 
Chrysanthemum cv. Marigold with two different moisture regimes under controlled conditions by gravimetric method.

\section{Materials and Methods}

The experiment was conducted under controlled condition at ICAR - Indian Institute of Horticultural Research, Bengaluru, to study the growth, yieldand physiological responses of chrysanthemum var. Marigold under two moisture regimes. The experiment was laid out in a completely randomized design. The experiment was carried out by growing plants in12-inch diameter plastic pots. The weight of empty pots was recorded. The Chrysanthemum var. Marigold cuttings were prepared from the maintained mother block and it were planted in portrays for rooting. The rooted cuttings were transplanted to the pots filled with $10 \mathrm{~kg}$ of uniform media containing red soil and farmyard manure (FYM) in the 1:1 (v/v) ratio after 30 days. The pots were maintained under protected condition to avoid rain.

\section{Imposing moisture regime treatments}

Two moisture regimes at $100 \% \mathrm{FC}$ and $70 \%$ FC were imposed during the period from 30 to $75 \mathrm{DAT}$. The pots were maintained at 70 and $100 \%$ FC by gravimetric method for a period of 45 days. Electronic weighing scale was used for weighing the pots and difference in the previous day was considered as the amount of water consumed and it was replenished.

\section{Gravimetric method}

The pot mixture (red soil and FYM in the 1:1 $(\mathrm{v} / \mathrm{v})$ ratio) was dried, and filled in the pot followed by the initial dry weight was taken. Then the soil was watered to maintain the field capacities i.e. 100\% FC and 70\% FC and the wet weight was taken. Then the next day the pot weight was taken to compute the difference between initial weight and final weight of the soil in the pot. The moisture regimes treatments were maintained by the replenishment of moisture based on the difference in the weight of the soil.

\section{Quantification of water use efficiency (WUE)}

The cumulative water transpired (CWT) was computed by subtracting the water added to the pots daily and evaporated water from the empty pots, the cumulative water transpired from the plants was summed up daily and expressed in $\mathrm{ml}$. The biomass accumulated during the treatment period (30 and 75 DAT) was estimated as the difference in the initial and final dry biomass and expressed as gram/plant. The average initial biomass was recorded by weighing uniform plants using destructive method at before imposing the treatments. Entire plant sample containing stems, leaves, roots and flowers were taken separately and dried using hot air oven at temperature of $70^{\circ} \mathrm{C}$, it is maintained and dry weight of samples were taken in grams. Total dry matter production was worked out by adding the average weight of different components of the crop and expressed in grams. The quantification of WUE involves the measurement of the dry matter accumulated over a particular period of time and the total water transpired by the plant during the same period. The water use efficiency was estimated by using following formula,

Water Use Efficiency $(\mathrm{g} / \mathrm{ml})=$ Total biomass produced by the plant $(\mathrm{g}) /$ cumulative water transpired from the plant $(\mathrm{ml})$

\section{Growth parameters}

The plant growth observations like, plant height, plant spread, number of primary and 
secondary branches/plant, number of leaves/plants were recorded at bud initiation stage.

\section{Yield parameters}

Yield parameters like, diameter of the flower head, number of flowers/plant, average weight of individual flowers, yield of flowers/plant and shelf life were recorded at flowering stage.

\section{Gas exchange characteristics}

Gas exchange characteristics i.e. photosynthetic rate (A) $\left(\mathrm{CO}_{2} \mu \mathrm{mol} \mathrm{m} \mathrm{m}^{-2} \mathrm{~s}^{-1}\right)$, stomatal conductance $(\mathrm{gs})\left(\mathrm{m} \mathrm{mol} \mathrm{H}_{2} \mathrm{O} \mathrm{m}^{-2}\right.$ $\left.\mathrm{s}^{-1}\right)$ and transpiration rate $(\mathrm{E})\left(\mathrm{m} \mathrm{H}_{2} \mathrm{O} \mathrm{m}^{-2} \mathrm{~s}^{-1}\right)$ were recorded at 9.00 am to 11.30 am by using Infra-red gas analyzer (IRGA) (Portable Photosynthesis System), Li - COR 6400 at flowering stage.

\section{Relative water content}

The relative water content (RWC) was also recorded at flowering stage from the freshly procured leaf samples. The fresh weight $(\mathrm{FW})$ of the leaf samples was taken immediately. Then the samples were stored at dark condition for $2 \mathrm{hrs}$ for taking turgid weight (TW), after that the samples were kept in an oven $\left(\right.$ at $\left.80^{\circ} \mathrm{C}\right)$ for a period of 24 hours. After 24 hours, the dry weight (DW) was taken. The relative water content was calculated by using following formula,

$$
\mathrm{RWC}(\%)=\frac{\text { FW-DW }}{\text { TW-DW }} \times 100
$$

\section{Results and discussion}

\section{Growth parameters}

The plants grown at $100 \%$ FC recorded highest plant height of $30.3 \mathrm{~cm}$ compared to plants maintained at $70 \% \mathrm{FC}(19.8 \mathrm{~cm})$. The plant height was affected by the low moisture at $70 \%$ FC (Table 1a). The height of the floral stem plays vital role in chrysanthemum, because it is a measure highly related to the production of the biomass and foliar area (Clement, 1995). According to Spadeto et al., (2018), when investigating the water replenishment levels in the pot chrysanthemum culture, it is observed that the maximum flower stems were found in the treatments in which the crop grown in high moisture condition. The two moisture regimes at $100 \%$ and $70 \% \mathrm{FC}$ showed significant difference in the number of leaves produced i.e.71.67 and 36.67 leaves/plant respectively. The average plant spread $(38.21 \mathrm{~cm})$ and total number of branches (11.34) also recorded higher in $100 \%$ field capacity. According to Taiz and Zeiger (2009), less moisture condition causes the roots to produce abscisic acid, the hormone responsible for decreased growth and leaf production. The treatment i.e. $70 \%$ FC with lower volumes of water applied, directly influenced the vegetative growth of chrysanthemum compared to high moisture condition. The high moisture level improved the growth characters of the plant, whereas the low moisture condition retarded the overall growth performances. These results were collaborating with the results found by Pereira et al., (2005) in chrysanthemum.

\section{Physiological parameters}

The treatments showed a decrease in fresh biomass with increase in low moisture condition. Plants maintained at $100 \%$ FC were tallest, therefore, they produced the greatest fresh biomass (Table 3 and Fig. 1), compared to $70 \%$ FC. In the treatments, the highest total fresh bio mass were recorded in $100 \%$ FC (153.09 g/plant), it was significantly higher than the biomass observed in $70 \% \mathrm{FC}$ (141.10 g/plant), It is known that the lowest rates of accumulation 
of biomass occurs where there is low moisture condition in the soil. The lowest range of accumulation bio mass occurs where there is water deficit in the soil (Loue, 2010). Since biomass production is the result of the photosynthetic activity and photo assimilates accumulation of the leaves, the efficiency with which the photo assimilates are converted. Under low moisture situation, the plants use the mechanism of closure of the stomata to avoid the loss of water, this mechanism also reducing the accumulation of photosynthates through photosynthetic activity, thus compromising the development of the plant, increased shoot (17.75 g/ plant of $100 \% \mathrm{FC}$ and $13.29 \mathrm{~g} /$ plant of $70 \% \mathrm{FC}$ ) and root biomass $(20.17 \mathrm{~g} /$ plant of $100 \% \mathrm{FC}$ and $16.29 \mathrm{~g} /$ plant of $70 \%$ FC) was occurs where the moisture content was more, similar results were observed by Chahal et al. (2018), Spadeto et al. (2018), Sarangi et al. (2015) and Farias et al. (2005).. Water restriction affected the biomass of leaves, the first operator of the photosynthetic activity (Olfa et al. 2018). The decrease in total dry weight may be due to the considerable decrease in overall plant growth, photosynthetic activity and canopy structure, as indicated by leaf senescence during low moisture level in the soil (Nautiyal et al. 2002).

Relative water content (RWC) in the leaves is the most appropriate way to measure plant water status. The relative water content was recorded higher in the leaves of plants treated with $100 \%$ FC (94.29\%) followed by plants treated with $70 \%$ FC (84.64\%) (Table 1b). This is supported with the findings of Jungklang and Saengnil (2012) that the plants grown under $100 \%$ FC was observed higher leaf water potential than the plants grown under $70 \% \mathrm{FC}$.

However, the root/shoot ratio was affected by moisture condition of the soil, indicating that the root/shoot ratio was higher $(0.42)$ in the plants grown under $70 \%$ FC compared to the plants under $100 \%$ FC (0.28) (Table 1b). This is supported with reports, that increase in root/shoot ratio with increased low moisture was observed in the plants extremely sensitive to low water condition and it is strongly influenced by the ability of the roots to grow in water deficit soil and maintain its optimal water status (Tyree and Dixon, 1986) and (Tyree and Alexander, 1993). According to Sobrado and Turner (1986), the similar rate of osmotic adjustment in root and leaf cells explained the similar root/shoot ratio found in low moisture and high moisture grown Helianthus annuus. Plants grown under low moisture i.e. $70 \%$ FC showed a significant difference in root length compared to the plants under $100 \%$ FC treatment. This significant difference could be illustrated by enhanced development of a longer root in search of limited amounts of water available in the soil. The root length of the plants under $70 \% \mathrm{FC}$ is $34.5 \mathrm{~cm}$ and $16.37 \mathrm{~cm}$ under 100 $\%$ FC (Table 1b). Reduced irrigation enhanced a deeper and more extensive rooting system. This would allow plants to use water and nutrients from deeper soil, thus increase both irrigation and nutrient use efficiency (Ngouajio et al., 2007).

The gas exchange characteristics were influenced by moisture regime treatments. Higher photosynthetic rate (A) $\left(7.56 \mathrm{CO}_{2} \mu\right.$ mol m $\left.\mathrm{m}^{-2} \mathrm{~s}^{-1}\right)$, stomatal conductance $(\mathrm{gs})(0.16$ $\mathrm{m} \mathrm{mol}\left(\mathrm{H}_{2} \mathrm{O}\right)\left(\mathrm{m}^{-2} \mathrm{~s}^{-1}\right)$ and transpiration rate (E) $\left(3.26 \mathrm{~m} \mathrm{H}_{2} \mathrm{O}\right)\left(\mathrm{m}^{-2} \mathrm{~s}^{-1}\right)$ were observed in plants at $100 \%$ FC compared to plants maintained under low moisture regime at 70 $\%$ FC which registered photosynthetic rate (A) $\left(5.16 \mu \mathrm{mol}\left(\mathrm{Co}_{2}\right)\left(\mathrm{m}^{-2} \mathrm{~s}^{-1}\right)\right.$, stomatal conductance $(\mathrm{Gs})\left(0.15 \mathrm{~m} \mathrm{~mol}\left(\mathrm{H}_{2} \mathrm{O}\right)\left(\mathrm{m}^{-2} \mathrm{~s}^{-1}\right)\right.$ and transpiration rate $(\mathrm{E})\left(2.22 \mathrm{~mol} \mathrm{H}_{2} \mathrm{O}\left(\mathrm{m}^{-2}\right.\right.$ $\mathrm{s}^{-1}$ ) (Table 2). The rate of transpiration was higher in the $100 \% \mathrm{FC}$ treatment compared to the low moisture treatment plants. The decrease in photosynthesis of leaves is usually 
caused by stomatal limitation under moderate low moisture conditions (Deglinnocenti et al., 2009; Misson et al., 2010). Low moisture conditions affect primly cell enlargement than cell division. It reduces the plant growth by inhibiting rate of photosynthesis, respiration, translocation, ion uptake, carbohydrates, nutrient metabolism and ultimately the overall growth and development of the plants (Farooq et al., 2009). In this study, the photosynthetic rate (A), stomatal conductance (Gs) and transpiration rate $(\mathrm{E})$, all showed a significant increase with increased field capacity (100\%) (Table 2), these results were highly associated with Zang et al., (2010). A reduction in the photosynthetic rate under low moisture conditions could be attributed either to a decrease in stomatal conductance (Jones (1998); Cornic and Massacci (1996)).The maintenance of the photosynthetic rate could be mainly attributed to the maintenance of stomatal conductance in plants (Spence et al., 1986). Low moisture level in the soil decreased the photosynthetic potential and affected the diurnal pattern of gas exchange there by, reducing plant growth. Low water condition was the main limitation to primary, photosynthetic process in lily (Zhang et al., 2010).

Fig.1 Effect of moisture regimes on total dry biomass (g/plant) production in chrysanthemum var. Marigold

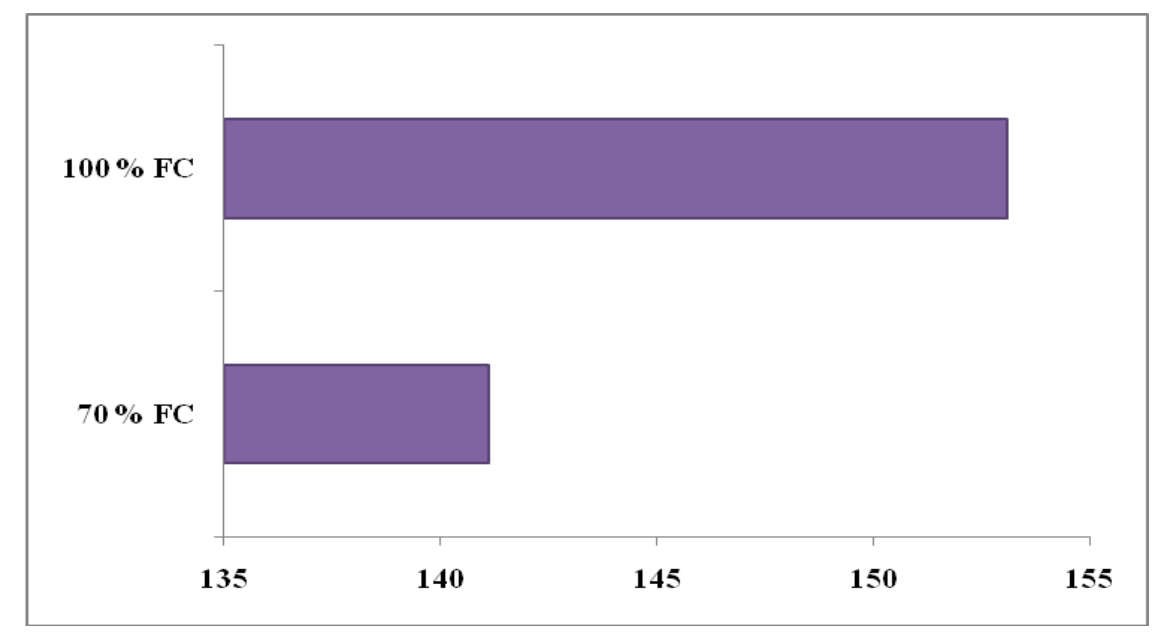

Fig.2 Effect of moisture regimes on WUE (g/litre of water) of chrysanthemum var. Marigold

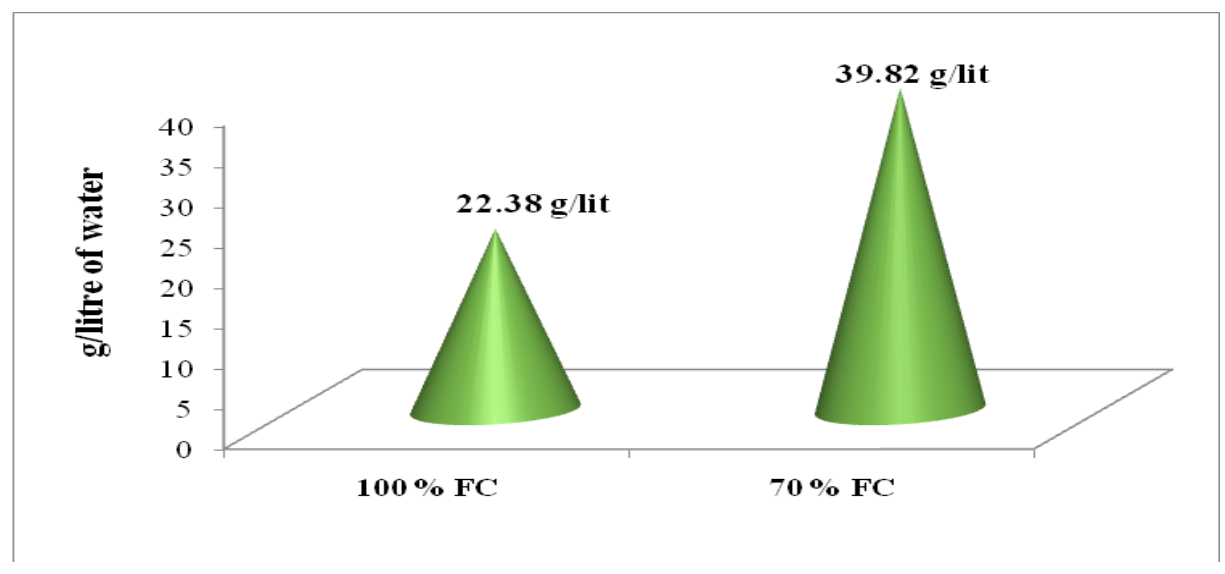


Plate.1 Effect of different moisture regimes on morphology of chrysanthemum var. Marigold under controlled condition

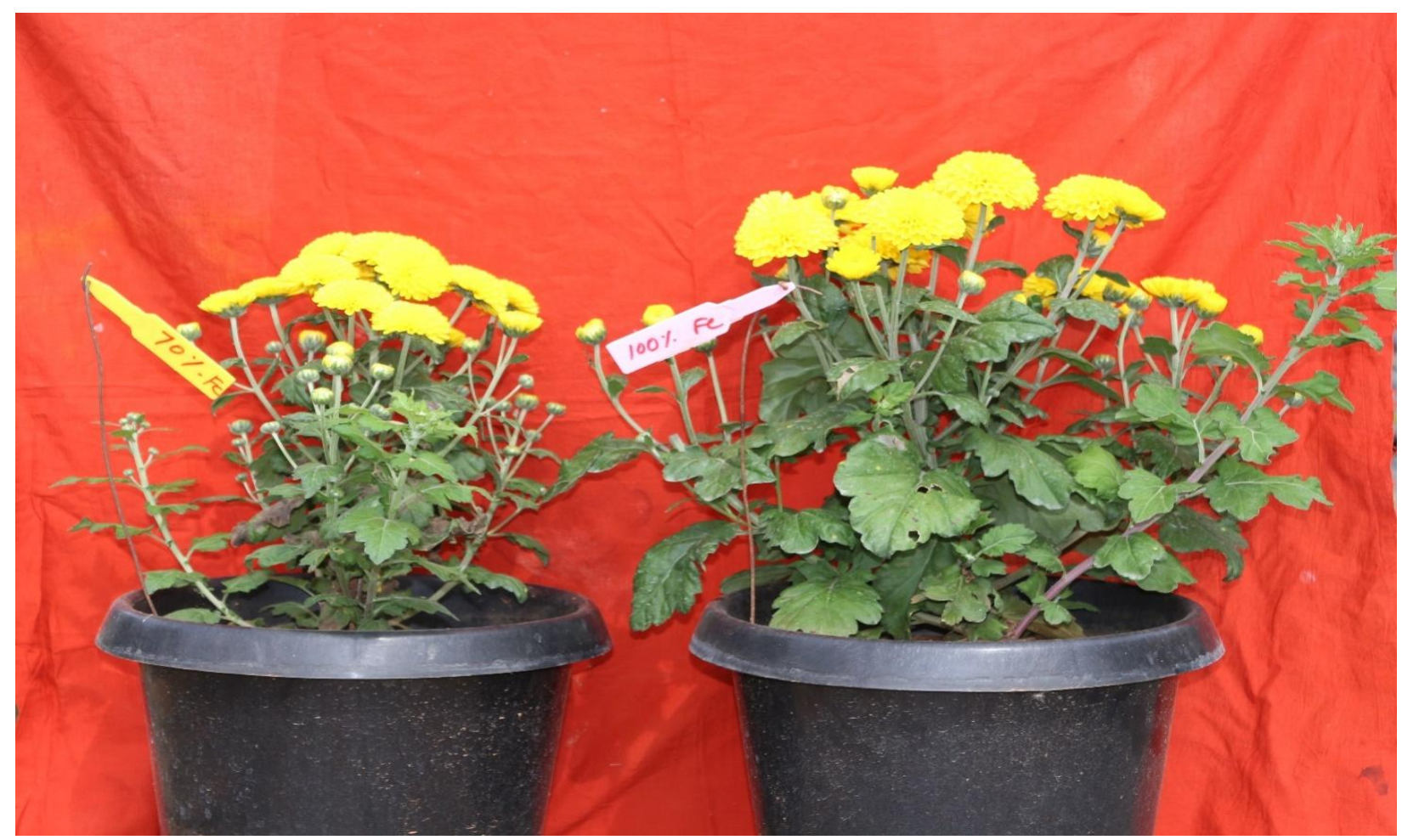

Plate.2 Effect of different moisture regimes on root growth of chrysanthemum var. Marigold under controlled condition

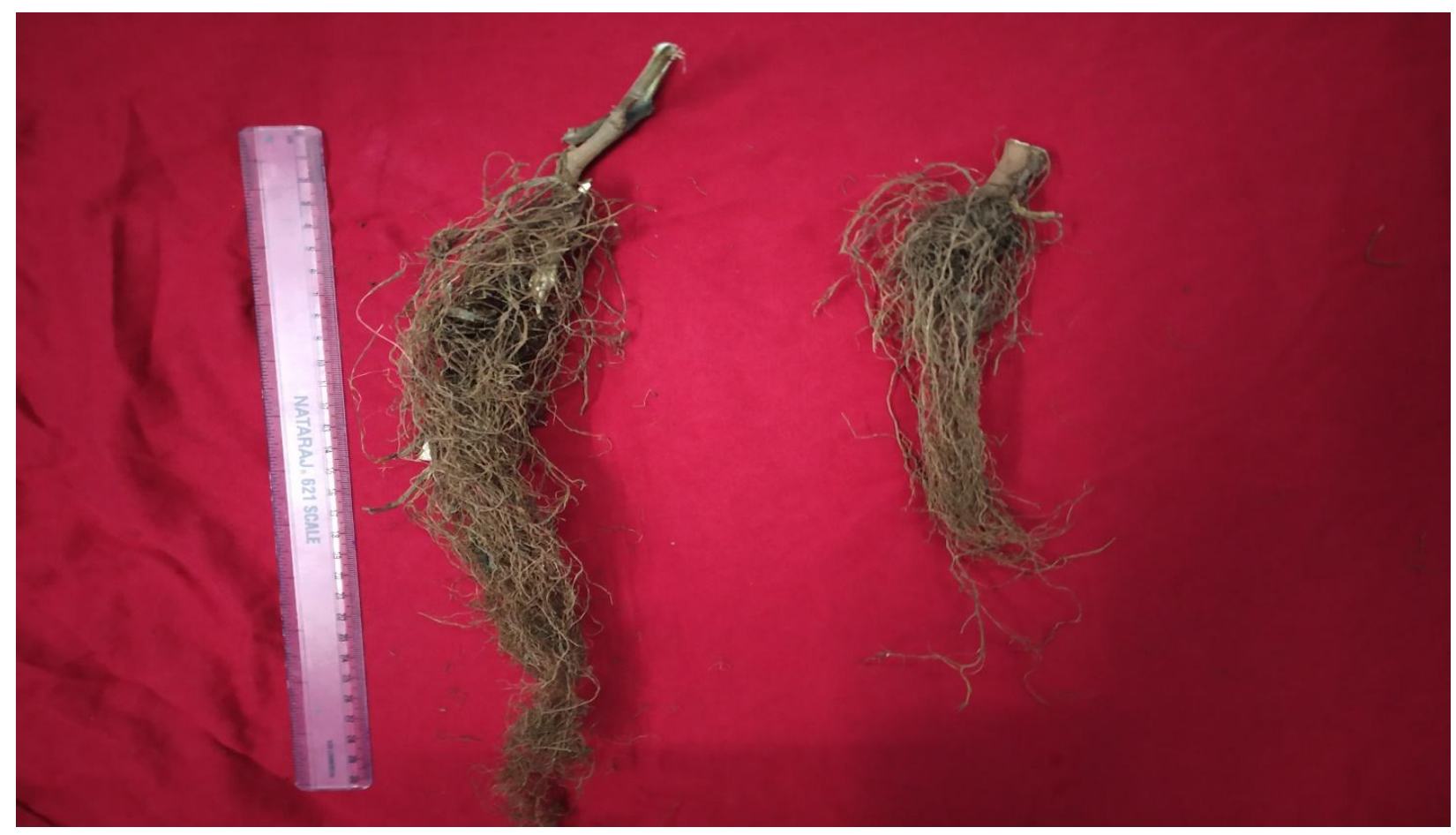


Table.1a Performance of chrysanthemum var. Marigold under different moisture regimes on growth and flowering parameters

\begin{tabular}{|c|c|c|c|c|c|c|c|}
\hline $\begin{array}{c}\text { Treatments } \\
\text { I }\end{array}$ & $\begin{array}{c}\text { Plant } \\
\text { height } \\
\text { Parameters }\end{array}$ & $\begin{array}{c}\text { Average } \\
\text { plant } \\
\text { spread } \\
\text { (cm) }\end{array}$ & $\begin{array}{c}\text { Primary } \\
\text { branches } \\
\text { / }\end{array}$ & $\begin{array}{c}\text { Secondary } \\
\text { pranches/ } \\
\text { plant }\end{array}$ & $\begin{array}{c}\text { Number of } \\
\text { leaves }\end{array}$ & $\begin{array}{c}\text { Diameter of } \\
\text { the flower } \\
\text { head (cm) }\end{array}$ & $\begin{array}{c}\text { Number of } \\
\text { flowers/plant }\end{array}$ \\
\hline $\mathbf{7 0 ~ \% ~ F C ~}$ & 19.81 & 28.38 & 3.00 & 2.42 & 36.67 & 4.18 & 87.92 \\
\hline $\mathbf{1 0 0} \% \mathbf{F C}$ & 30.33 & 38.21 & 5.67 & 5.67 & 71.67 & 5.93 & 136.75 \\
\hline SE d & $\mathbf{0 . 7 0}$ & $\mathbf{2 . 3 2}$ & $\mathbf{0 . 6 3}$ & $\mathbf{0 . 5 9}$ & $\mathbf{5 . 0 1}$ & $\mathbf{0 . 2 6}$ & $\mathbf{6 . 0 2}$ \\
\hline CD @ 5\% & $\mathbf{1 . 4 6}$ & $\mathbf{4 . 8 1}$ & $\mathbf{1 . 3 1}$ & $\mathbf{1 . 2 2}$ & $\mathbf{1 0 . 3 9}$ & $\mathbf{0 . 5 5}$ & $\mathbf{1 2 . 4 9}$ \\
\hline
\end{tabular}

Table.1b Performance of chrysanthemum var. Marigold under different moisture regimes on yield and physiological attributes

\begin{tabular}{|c|c|c|c|c|c|c|c|}
\hline $\begin{array}{l}\text { Treatments / } \\
\text { Parameters }\end{array}$ & $\begin{array}{l}\text { Average } \\
\text { weight of } \\
\text { individual } \\
\text { flowers (g) }\end{array}$ & $\begin{array}{c}\text { Yield of } \\
\text { flowers per } \\
\text { plant (g) }\end{array}$ & $\begin{array}{c}\text { Shelf life } \\
\text { (Days) }\end{array}$ & $\begin{array}{c}\text { Root: } \\
\text { shoot ratio }\end{array}$ & $\begin{array}{l}\text { Length of } \\
\text { root } \\
(\mathbf{c m})\end{array}$ & RWC (\%) & $\begin{array}{c}\text { Total } \\
\text { Fresh } \\
\text { Biomass } \\
\text { (g) }\end{array}$ \\
\hline $70 \% \mathrm{FC}$ & 5.38 & 550.00 & 4.92 & 0.42 & 34.50 & 84.64 & 141.10 \\
\hline $100 \% \mathrm{FC}$ & 7.21 & 881.67 & 7.58 & 0.28 & 16.37 & 94.29 & 153.09 \\
\hline SE d & 0.37 & 35.95 & 0.39 & 0.29 & 0.43 & 1.30 & 1.34 \\
\hline CD@ $@ 5 \%$ & 0.76 & 74.55 & 0.80 & 0.45 & 0.89 & 2.71 & 2.78 \\
\hline
\end{tabular}

Table.2 Effect of different moisture regimes on gas exchange characteristics of chrysanthemum var. Marigold under controlled condition

\begin{tabular}{|c|c|c|c|}
\hline $\begin{array}{l}\text { Treatments / } \\
\text { Parameters }\end{array}$ & $\begin{array}{l}\text { Photosynthetic } \\
\text { rate (A) } \\
\text { micro mol (Co2) } \\
\left(\mathrm{m}^{-2} \mathrm{~s}^{-1}\right)\end{array}$ & $\begin{array}{l}\text { Transpiration } \\
\text { rate }(\mathrm{E}) \\
\text { milli mol }\left(\mathrm{H}_{2} \mathrm{O}\right) \\
\quad\left(\mathrm{m}^{-2} \mathrm{~s}^{-1}\right)\end{array}$ & $\begin{array}{c}\text { Stomatal } \\
\text { conductance (GS) } \\
\text { Mol } \mathrm{H}_{2} \mathrm{O}\left(\mathrm{m}^{-2} \mathrm{~s}^{-1}\right)\end{array}$ \\
\hline $70 \% \mathrm{FC}$ & 5.16 & 2.22 & 0.15 \\
\hline $100 \% \mathrm{FC}$ & 7.56 & 3.26 & 0.16 \\
\hline SE d & 1.14 & 0.40 & 0.04 \\
\hline CD@ $9 \%$ & 2.37 & 0.83 & 0.08 \\
\hline
\end{tabular}


Table.3 Effect of different moisture regimes on biomass, cumulative water transpired and water use efficiency of chrysanthemum var. Marigold

\begin{tabular}{|c|c|c|c|c|c|}
\hline Treatments & $\begin{array}{c}\text { Cumulative } \\
\text { water } \\
\text { Transpired/plant } \\
\text { (ml) }\end{array}$ & $\begin{array}{c}\text { Root } \\
\text { biomass (g) }\end{array}$ & $\begin{array}{c}\text { Shoot } \\
\text { biomass (g) }\end{array}$ & $\begin{array}{l}\text { Total fresh } \\
\text { biomass } \\
\text { produced during } \\
\text { treatment period } \\
\text { (g/plant) }\end{array}$ & $\begin{array}{c}\text { WUE } \\
\text { (g/litter } \\
\text { of } \\
\text { water) }\end{array}$ \\
\hline \multicolumn{6}{|c|}{$100 \% \mathrm{FC}$} \\
\hline T1R1 & 6380 & 17.50 & 13.50 & 147.80 & 20.80 \\
\hline T1R2 & 5370 & 14.50 & 10.50 & 148.30 & 26.57 \\
\hline T1R3 & 5470 & 14.50 & 12.00 & 152.30 & 27.00 \\
\hline T1R4 & 5020 & 18.00 & 13.00 & 155.30 & 31.61 \\
\hline T1R5 & 6910 & 15.50 & 14.50 & 157.80 & 21.95 \\
\hline T1R6 & 5650 & 17.00 & 14.50 & 157.30 & 28.80 \\
\hline T1R7 & 5900 & 17.00 & 15.00 & 152.80 & 22.49 \\
\hline \multicolumn{6}{|c|}{$70 \% \mathrm{FC}$} \\
\hline T2R1 & 5710 & 18.50 & 15.50 & 143.80 & 39.00 \\
\hline T2R2 & 5500 & 17.50 & 16.00 & 135.80 & 42.31 \\
\hline T2R3 & 5220 & 19.50 & 17.50 & 139.80 & 46.49 \\
\hline T2R4 & 4850 & 20.00 & 18.50 & 141.90 & 49.01 \\
\hline T2R5 & 5770 & 21.00 & 19.00 & 142.80 & 35.13 \\
\hline T2R6 & 5980 & 22.00 & 18.50 & 142.80 & 33.90 \\
\hline T2R7 & 6250 & 21.00 & 17.00 & 140.80 & 31.95 \\
\hline SE (d) & 0.09 & 2.21 & 1.44 & 1.68 & 1.28 \\
\hline CD@5\% & 1.06 & 4.01 & 2.87 & 3.22 & 2.47 \\
\hline
\end{tabular}

\section{Yield and quality parameters}

When comparing the yield and quality parameters of chrysanthemum var. Marigold under two moisture regimes (Table 1a), it was observed that the total number of flowers/plant was significantly higher in treatment with $100 \%$ field capacity (136.75) compared to plants under $70 \%$ of field capacity (87.92). This result was supported with the findings of Taweesak et al., (2014) in chrysanthemum. The weight of individual flowers and hundred flower weight was increased with enhanced moisture level in the soil and was directly proportional to the plant biomass. The increased vegetative growth directly influenced the weight of individual flowers. The plants maintained under $100 \%$
FC recorded maximum individual flower weight $(7.21 \mathrm{~g})$ when compared to weight of individual flowers in $70 \% \mathrm{FC}(5.38 \mathrm{~g}$ ) (Table $1 b)$. The best quality flowers were obtained in the plants under field capacity of $100 \%$, according to Farias et al., (2005). Superior quality of flowers with extended shelf life (7.58 days) was observed in plants at $100 \mathrm{FC}$ $\%$ compared to plants under $70 \%$ FC (4.92 days) (Table 1b). The yield of flowers under $100 \%$ FC was recorded significantly $(881.67$ $\mathrm{g} /$ plant) than the yield of plants under $70 \%$ FC (550.0 g/plant) (Table $1 \mathrm{~b}$ and Fig. 2). These results were supported with the findings of Spadeto et al., (2018) in chrysanthemum. Effective utilization of irrigation water, soil nutrients, higher photosynthetic rate as well as enhanced 
translocation of photosynthates under higher moisture environment were responsible for achieving the highest yield (Ngouajio et al., 2010). The diameter of the flower head was lower $(4.18 \mathrm{~cm})$ with low moisture regimes (70 \% FC) whereas higher flower head diameter $(5.93 \mathrm{~cm})$ was observed in $100 \%$ FC (Table 1a). The higher moisture regime enhanced the flower and flower quality characteristics, than the low moisture regime treatment. This was in accordance with the findings of Nazarideljou et al., (2015) in zinnia.

\section{Water use efficiency (WUE)}

The water use efficiency is an index to quantify the use efficiency of water resources towards crop production. Under limited water supply condition, WUE plays crucial role to screen suitable irrigation regimes. Water use efficiency was higher in plants maintained at $70 \%$ FC. These results were also confirming the statement of Arquero et al., (2006), which shows that plants grown at $100 \%$ FC had lower water use efficiency than plants under $70 \%$ FC. The WUE were recorded in plants under $70 \%$ FC treatment was $39.82 \mathrm{~g} /$ litter of water, when the plants under high moisture condition i.e. $100 \%$ FC was 22.38 g/litter of water (Table 3 and Fig. 2). Enhanced water uptake through investments in the root system can result in reduced plant size and water expenditure for growth maintenance can observed in plants grown under low moisture situation (Lopes et al., 2011). The highest WUE was found in the lowest level of moisture at $70 \%$ FC, indicating comparatively more efficient use of irrigation water than higher moisture level. This is in conformity with the report that water use efficiency (WUE) is reduced with increasing soil moisture availability by Waraich et al., (2011) and Jawaharlal et al., (2017). In conclusion, performance of chrysanthemum var. Marigold was highly influenced by moisture regimes treatment in terms of growth, physiological, yield and quality parameters under controlled condition. Soil at $100 \%$ FC was significantly increased the plant height, average plant spread, number of branches/plant, number of flowers/plant, average weight of individual flowers, RWC, root and shoot biomass, total fresh biomass, gas exchange characteristics i.e. photosynthetic rate, stomatal conductance and transpiration rate compared to $70 \%$ field capacity treatment. However, water use efficiency (WUE) of chrysanthemum increased under low moisture condition $(70 \%$ FC) compared to $100 \%$ FC. The improvement in physiological parameters had significantly influenced the growth, yield, quality and shelf life of flowers under moisture regimes. It is concluded that the higher moisture regime i.e. $100 \%$ FC enhanced the plant growth, yield and quality aspects as compared to low moisture regime.

\section{References}

Andersson, N.E. 2001. Weight controlled irrigation of potted plants. Acta Horticulturae. 559: 371-5.

Arif, T., Yusuf Ucar and Soner Kazaz. 2015. Effects of different irrigation treatments on quality parameters of cut chrysanthemum, Scientific Papers. Series B, Horticulture. Vol. LIX.

Arquero, O. 2006. Potassium Starvation Increases Stomatal Conductance in Olive Trees". Hort. Science, 41.2: 433436.

Budiarto K., Sulyo Y., Dwi, E.S.N., Maaswinkel R.H.M., 2007. Effects of irrigation frequency and leaf detachment on chrysanthemum grown in two types of plastic house. Indonesian Journal of Agricultural Science, 8(1): 39-42.

Carvalho S.M.P., Abi-Tarabi, H., Heuvelink E. 2005. Temperature affects 
Chrysanthemum flower characteristics differently during three phases of the cultivation period. Journal of Horticultural Science and Biotechnology, 80(2), pp. 209-216.

Chahal, P. S., Varanasi, V. K., Jugulam, M. and Jhala, A. J. 2017. Glyphosateresistant Palmer amaranth (Amaranthus palmeri) in Nebraska: confirmation, EPSPS gene amplification, and response to post corn and soybean herbicides. Weed Technol., 31:80-93

Chandi, A., Jordan, D. L., York, A. C., Burton, J., Milla Lewis, S. R., Spears, J, Whitaker, J. R. and Wells, R. 2013. Response of herbicide resistant Palmer amaranth (Amaranthus palmeri) accessions to drought stress. Int $J$ Agron. 10.1155/ 2013/823913

Chauhan, B. S. 2013. Growth response of itch grass (Rottboellia cochinchinensis) to water stress. Weed Sci., 61:98-103

Chauhan, B. S. and Johnson, D. E. 2010. Growth and reproduction of jungle rice (Echinochloa colona) in response to water-stress. Weed Sci., 58:132-135

Clement, C.R. (1995) Growth and genetic analysis of pejibaye (Bactris gasipaes Kunth, Palmae) in Hawaii. Ph.D dissertation. University of Hawaii at Manoa, Honolulu, HI, 221.

Conover C.A., 1969. Responses of Pot-Grown Chrysanthemum morifolium 'Yellow Delaware' to Media, Watering and Fertilizer Levels. Proceeding of the Florida State Horticultural Society, 82, 425-429.

Castro A.M., Macedo Junior E.K., Zigiotto D.C., Braga C.L., Sornberger A., Baldo M., Grisa S., Bianchini M.I.F., Sausen C., 2005. Effect of Irrigation Layers on Varieties of Chrysanthemum for Cutting and on Soil Characteristics. Scientia Agraria Paranaensis, 4(2), 75-80.

Cornic, G. and Massacci, A. 1996. Leaf photosynthesis under drought stress. In:
Baker NR, ed. Photosynthesis and the environment. The Netherlands: Kluwer Academic Publishers.

Deglinnocenti, E., Hafsi C., Guidi L. and Navari-Izzo F. 2009. The effect of salinity on photosynthetic activity in potassium-deficient barley species. $J$. Plant Physiol. 166, 1968-1981.

Earl, H. J., 2003. A precise gravimetric method for simulating drought stress in pot experiments. Crop Sci., 43: 18681873

Farias, M.F., De Saad, J.C.C. and Denise, M.C., 2009. Effect of soil-water tension on cut chrysanthemum floral quality and longevity. Applied Research \& Agrotechnology 2(1): 141-145.

Farias, M. F. and Saad, J.C.C. 2005. Analysis of the growth of pot chrysanthemum, puritan cultivar, irrigated under different substrate water tensions in greenhouse. Acta Scientiarum. Agronomy, 33(1): 75-79

Farooq, M., Wahid, A., Kobayashi, N., Fujita, D and Basra, S.M.A. 2009. Plant drought stress: effects, mechanisms and management. Agron. Sustain. Dev., 29: $185-212$

Fernandes A.L.T., Folegatti M., Pereira A.R., 2006. Valuation of different evapotranspiration estimate for (Chrysanthemum spp.) cultivated in plastic greenhouse. Irriga. 11(2): 139149.

Harbaugh B.K., Stanley C.D., Price J.F., 1985. Tricle Irrigation Rates for Chrysanthemum Cut Flower Production. Proceeding of the Florida State Horticultural Society, 98, 110114.

Jaleel, C.A., Gopi, R., Sankar, B., Gomathinayagam, M. and Panneerselvam, R. 2008. Differential responses in water use efficiency in two varieties of Catharanthus roseus under drought stress. Comp.Rend. Biol., 331: 
$42-47$

Janakiram, T., Mahantesh, Murgod, I. and Prabhakar, B. S. 2006. Standardization of agro techniques for production of Chrysanthemum under low cost poly house. Acta Horticulturae, 710: 321328.

Jawaharlal, D., Manoj Kumar, G., Srinivasulu, M and Manohar Rao, A. 2017. Water Use Efficiency of Chrysanthemum Crop for Different Mulches under Drip Irrigation System in Semi Arid Region. Inter. J. of Agriculture Sci., ISSN: 0975-3710 \& EISSN: 0975-9107, Volume 9, Issue 8, pp.-3859-3861.

Johnson, C. R., D.L. Ingram, and J.E. Barrett. 1981. Effects of irrigation frequency on growth, transpiration, and acclimatization of FicusbenjaminaL. HortScience. 16:80-81.

Jones H.G., Tardieu F. (1998) Modelling water relations of horticultural crops: a review. Scientia Horticulturae, 74, pp. 21-46.

Jones, H.G. (1998). Stomatal control of photosynthesis and transpiration. J. Exp. Bot. 49:387-398

Jungklang and Saengnil, 2012. Effect of paclobutrazol on Patumma cv. Chiang Mai Pink under water stress. J. Sci. Technol., 34 (2012), pp. 361-366

Kazaz S., Aşkın M.A., Kılıç S., Ersoy N., 2010. Effects of day length and daminozide on the flowering, some quality parameters and chlorophyll content of Chrysanthemum morifolium Ramat. Scientific Research and Essays 5(21): 3281-3288.

Kiehl P.A., Lieth J.H., Burger D.W., 1992. Growth Response of Chrysanthemum to Various Container Medium Moisture Levels. Journal of American Society for Horticultural Science. 114(2): 224-229

Koley, S. and Sarkar, M. M. 2013. Measurement of PAR and its impact on chrysanthemum (Chrysanthemum morifolium Ramat). The Bioscan, 8(1):169-72.

Lieth, J.H. and D.W. Burger. 1989. Growth of chrysanthemum using an irrigation system controlled by soil moisture tension. J. Amer. Soc. Hort. Sci. 114:387-392.

Lima Júnior IS, Bertoncello TF, Melo EP, Degrande PE and Kodama C. 2010. Artificial defoliation simulating pest damage on sunflower. Revista Ceres., 57(1):23- 27.

Lin L., Li W., Shoa J., Luo W., Dai J., Yin X., Zhou Y., Zhao C. 2011. Modelling the effects of soil water potential on growth and quality of cut chrysanthemum (Chrysanthemum morifolium). Scientia Horticulturae, 130, pp. 275-288.

Lopes, M.S., Araus, J.L., Van Heerden, P.D.R., and Foyer, C.H. 2011. Enhancing drought tolerance in $\mathrm{C} 4$ crops. J. Exp. Bot., 62, 3135-3153.

Marjorie de Freitas Spadeto, Giovanni de Oliveira Garcia and EdvaldoFialho dos Reis. 2018. Effects of Different Levels of Water Deficit on the Soil in Chrysanthemum Culture. 2018. Inter. J. of Exp. Agriculture, 23(1): 1-7, 2018;

Misson, L., Limousin, J. M., Rodriguez, R. and Letts, M. G. 2010. Leaf physiological responses to extreme droughts in Mediterranean Quercus ilex forest. Plant Cell Environ. 33, 18981910.

Nautiyal, P.C., Ravindra, V. and Joshi, Y.C. 2002. Dry matter partitioning and water use efficiency under water-deficit during various growth stages in groundnut, Indian J. Plant Physiol. 7: 135-139.

Nazarideljou, J., Heidari, Z., Hamedan, and H. Jaberian. 2015. Effect of Glomousmosseae inoculation on growth and flower quality of zinnia bedding plants under different drought levels. 
Acta Horticulturae, no.1104 pp. 73-78.

Ngouajio, M., Wang, G. and Goldy, R. 2007. Withholding of drip irrigation between transplanting and flowering increases the yield of field-grown tomato under plasticmulch. Agric. Water Manage. 87:285-291.

OlfaBoussadia, Mortadha Ben Hassine and Mohamed Braham. 2018. Effect of Water Stress on Photosynthetic Assimilation and Biomass Accumulation in Olive Tree. Acta Scientific Agriculture. 2.10: 84-92.

ParivaDobriyal, Ashi Qureshi, Ruchi Badola, Syed Ainul Hussain. 2012. A review of the methods available for estimating soil moisture and its implications for water resource management.Journal of Hydrology. 458-459: 110-117.

Parnell J.R., 1989. Ornamental plant growth responses to different application rates of reclaimed water. Proceedings of the Florida State Horticultural Society, 102, 89-92. Rego J.L., Viana T.V.A., Azevedo B.M., Bastos F.G.C., Gondim R.S., 2004. Effects of irrigation levels on the chrysanthemum. Agronomic Science Magazine 35(2): 302-310.

Pereira, J. R. D., Carvalho, J. A., Miguel, D. S. and Santana, M. J. 2005. Water requirement by chrysanthemum cultivated under greenhouse conditions. Engenharia Agricola. 2005; 25 (3):651659.

Peri, P.L., Moot, D.J., McNeil, D.L. 2003. A canopy photosynthesis model to predict the dry matter production of cocksfoot pastures under varying temperature, nitrogen and water regimes. Grass and Forage Science, 58, pp. 416-430.

Posse, R.P., Gabriel Fornaciari, Edinei José Armani Borghi, FranciellyValani, Sophia Machado Ferreira da Silva, Evandro Chaves de Oliveira and Geilson Silva Costa. 2019. Influence of Irrigation Depths on the Growth of
Chrysanthemum, Cultivated in Pots, in a Greenhouse in the Northwest Region of Espírito Santo. Journal of Experimental Agriculture International. 31(2): 1-11

Rober, R. and M. Hafez. 1981. The influence of different water supply upon the growth of chrysanthemums. Acts Hort. 125:69-78.

Sarangi, D., Irmak, S., Lindquist, J. L., Knezevic, S. Z. andJhala, A. J. 2015. Effect of water stress on the growth and fecundity of common water hemp (Amaranthus rudis). Weed Science, 64:42-52

Schmugge, T., Jackson, T.J., McKim, H.L., 1980. Survey of methods for soil moisture determination. Water Resour. Res. 16 (6), 961-979.

Schuch U.K., Redak R.A., Bethke J.A., 1998. Cltivar, fertilizer and irrigation affect vegetative growth and susceptibility of Chrysanthemum to western flower thrips. J. Amer. Soc. Hort. Sci 123(4): 727-733.

Sobrado, M. A. and Turner NC. 1986. Photosynthesis, dry matter accumulation and distribution in the wild sunflower (Helianthus petiolaris) and the cultivated sunflower (Helianthus annuus) as influenced by water deficits. Oecologia, 69: 181-187.

Sohier, G., Sayed, Magda, M., Hassanien and Eman, A. Swedan. 2008. Effect of irrigation regimes on chrysanthemum flowering under nitrogen fertilization levels. Journal of Agriculture \& Environmental Sciences, 7(3).

Spence, R. D., Wu, H., Sharpe, P. J. H., and Clark, K. G. 1986. Water stress effects on guard cell anatomy and the mechanical advantage of the epidermal cells. Plant Cell Environ. 9, 197-202.

Spomer, L.A. and R.W. Langhans. 1975. The growth of greenhouse bench Chrysanthemum x morifolium Ramat. at 
high soil water contents: Effects of water and aeration. Commun. in Soil Sci. \& Plant Anal. 6(5): 545-553.

Taweesak, V., Abdullah, T. L., Hassan, A. S., Kamarulzaman, N. H. and Yusoff, W.A.W. 2014. Growth and Flowering Responses of Cut Chrysanthemum Grown under Restricted Root Volume to Irrigation Frequency.The Scientific World Journal, Article ID 254867, 6 pages

Tyree, M. T. and Dixon, M. A. 1986. Water stress induced cavitation and embolism in some woody plants. Physiol. Plant. 66: 397-405.

Tyree, M.T. and Alexander, J.D., 1993. Plant water relations and the effects of elevated $\mathrm{CO}_{2}$ : a review and suggestions for future research. Vegetation, 104/105, 47-62.

Villalobos R., 2014. Reduction of irrigation water consumption in the Colombian Floriculture with the use of tensiometer. http://irrigationtoolbox.com/ReferenceD
ocuments/Technical

Papers/IA/2007/P1642.pdf

Waraich, E. A., Ahmad, R., and Ahmad, S. S. 2008. Water use efficiency and yield performance of wheat (Triticum aestivum L.) under different levels of irrigation and nitrogen. Caderno de Pesquisase rie Biologia, 20, 22 -34

Waterland N.L., Finer J.J., Jones M.L., 2010. Abscisic acid applications decrease stomatal conductance and delay wilting in drought-stresses chrysanthemums. Hort. Technology 20(5): 896-901.

Wikle, J. S., H. Davidson, and E. Erickson. 1961. Soil moisture studies with container grown plants. Mich. Quart. Bul. 44(1):125-128.

Zhang, L. R., Niu, H. S., Wang, S. P., Li, Y. N., and Zhao, X. Q. 2010. Effects of temperature increase and grazing on stomatal density and length of four alpine Kobresia meadow species, Qinghai-Tibetan Plateau. Acta Ecol. Sin. 30, 6961-6969.

\section{How to cite this article:}

Vijayakumar, S., R. H. Laxman, Sujatha Anil Nair and Anil Kumar Nair. 2020. Effect of Different Moisture Regimes on the Yield, Quality and Water Use Efficiency of Chrysanthemum var. Marigold. Int.J.Curr.Microbiol.App.Sci. 9(04): 3138-3151. doi: https://doi.org/10.20546/ijcmas.2020.904.366 